\title{
Analisis Finansial Usaha Abon Ikan Pada Kelompok Pengolahan Ikan Pantura Di Kelurahan Humusu C Kecamatan Insana Utara Kabupaten Timor Tengah Utara
}

\author{
Leonardus Kaet ${ }^{\mathrm{a}}$, dan Adeline Norawati Hutapea ${ }^{\mathrm{b}}$ \\ ${ }^{a}$ Fakultas Pertanian, Universitas Timor, Kefamenanu, Indonesia. \\ ${ }^{b}$ Fakultas Pertanian, Universitas Timor, Kefamenanu, Indonesia.
}

\section{Article Info}

Article history:

Received 11 Mei 2016

Received in revised form 19 Juni 2016

Accepted 26 September 2016

\section{Keywords:}

Analisis Finansial

Abon Ikan

Pantura

Humusu C

\section{Abstrak}

Penelitian ini bertujuan untuk menganalisis kelayakan usaha Abon ikan dengan menggunakan NPV, IRR, Net B/C, ROI, dan BEP. Hasi penelitian menunjukkan bahwa Kelompok pengolahan ikan Pantura merupakan salah satu kelompok yang dibentuk pada tahun 2012 yang terletak di Kelurahan Humusu C Kecamatan Insana Utara. Kelompok ini terkenal dengan ciri khas usahanya berbahan baku ikan yakni Abon Ikan. Kelompok Pengolahan ikan Pantura menjadi wadah berkumpulnya beberapa Ibu Rumah Tangga yang berusaha untuk membantu dan menambah pendapatan yang belum maksimal memenuhi dan membiayai kebutuhan dalam rumah tangga mereka sehingga $100 \%$ tenaga kerja berasal dari dalam kelompok. Pada tingkat suku bunga $12 \%$ usaha Abon ikan Pantura merk Anggrek layak untuk dikembangkan dengan nilai NPV Rp. 3700.383. IRR 29,61\% (lebih besar dari nilai suku bunga pinjaman yang digunakan $12 \%$ ); Net B/C 1,02; ROI 20,79\% dan nilai Break Event Point (BEP) sebesar 435 unit/tahun atau usaha abon ikan di Kelurahan Humusu C akan mencapai titik impas jika mereka memproduksi abon ikan sebanyak 435 unit per tahun, dan sampai saat ini produksi abon ikan dari pusat usaha abon ikan di Kelurahan Humusu C rata-rata bisa mencapai produksi 480 unit per tahun. Hal ini menandakan bahwa usaha abon ikan ini bisa dikembangkan karena memberikan keuntungan yang besar. @2016 dipublikasikan oleh Agrimor.

\section{Pendahuluan}

Usaha mempunyai peranan yang penting dalam roda pembangunan ekonomi di era globalisasi. Bermodalkan potensi sumber daya alam dan daya dukung besar dari ekosistem yang ada, dapat menghasilkan produk-produk baik di sektor perikanan maupun usaha. Sektor perikanan sebagai penyedia bahan baku sedangkan sektor usaha sebagai pengolah bahan baku tersebut untuk mendapatkan nilai tambah.

Potensi tangkapan ikan tongkol dan ikan cakalang di Kabupaten Timor Tengah Utara (TTU) pada 3 tahun terakhir terhitung dari tahun 2013-2015 sebanyak 70,2 ton/tahun dengan rincian jumlah tangkapan ikan tongkol sebanyak 60,5 ton/tahun dan ikan cakalang sebanyak 9,7 ton/tahun yang tersebar di 3 kecamatan dengan luas wilayah tangkapan $900 \mathrm{~m}^{2}$ dan panjang garis pantai 50 $\mathrm{km}^{2}$. Dilihat dari tingkat tangkapan ikan seperti data di atas menandakan bahwa ketersediaan bahan baku dalam hal ini ikan sangat memungkinkan dem keberlanjutan produksi bagi kelompok-kelompok pengolahan di wilayah Kabupaten TTU (DKP TTU, 2015).

Kelompok pengolahan ikan dengan nama Pantura dikenal sebagai salah satu kelompok pengolahan dalam percaturan usaha berbasis perikanan yang terdapa di Kelurahan Humusu C Kecamatan Insana Utara sejak tahun 2012. Usaha in memanfaatkan komoditi Ikan cakalang dan tongkol sebagai bahan baku. Ikan diolah dalam kegiatan produksinya menjadi Abon ikan.

Usaha ini awal mulanya dibentuk atas dasar inisiatif sendiri yang mana apabila dilihat dari segi permodalan diawal proses produksi, usaha ini hanya menggunakan modal sendiri. Pembuatan abon menjadi alternatif pengolahan ikan dalam rangka penganekaragaman produk perikanan dan mengantisipasi melimpahnya tangkapan ikan dimasa panen.

Permasalahan dalam sektor hilir perikanan adalah keberlanjutan bahan baku dalam hal ini ikan cakalang dan ikan tongkol yang ketersediaannya selalu berfluktuasi demi peningkatan produksi olahan serta kurangnya kemampuan untuk mengembangkan diversifikasi produk diantaranya proses pengolahan sampai pada proses pembungkusan serta pemberian label yang akan berpengaruh terhadap nilai ekonomis dari produk abon ikan dan besaran kontribusi sektor kelautan dan perikanan terhadap pembangunan ekonomi secara komprehensif d Kabupaten TTU terutama pada kelompok pengolah Ikan Pantura apabila diliha dari segi ekonomis layak ataukah tidak layak usaha tersebut. Jenis usaha yang didirikan akan berpengaruh pada analisa kelayakan finansial. Berbeda jenis usaha maka akan berbeda dalam perhitungan analisis kelayakan finansial, terutama pada usaha yang masih bersifat baru. Kadariah et al. (1999) menyatakan bahwa ada dua macam analisis yang biasa digunakan dalam mengevaluas kelayakan usaha, yaitu analisis finansial dan analisis ekonomi. Analisis finansia adalah suatu kajian terhadap biaya dan manfaat di dalam suatu usaha yang diliha dari sudut badan atau orang-orang yang menanam modalnya atau yang berkepentingan langsung dalam usaha tersebut.

Tujuan penelitian ini adalah mendeskripsikan gambaran umum Usaha Abon Ikan Pada Kelompok Pengolahan Ikan Pantura dan mendeskripsikan kelayakan secara finansialnya.

\section{Metode}

Penelitian ini akan dilaksanakan di Kelurahan Humusu C Kecamatan Insana Utara Kabupaten Timor Tengah Utara Pada bulan Oktober sampa Februari tahun 2016. Metode pengambilan sampel yang digunakan dalam penelitian ini secara Purposive sampling artinya pengambilan sampel dilakukan pada ketua kelompok pengolahan ikan Pantura. Data yang dikumpulkan kemudian dianalisis menggunakan analisis deskriptif kualitasif sesuai petunjuk Nasir (1988) untuk mendapatkan gambaran umum usaha abon ikan, selanjutnya dilakukan analisis kelayakan usaha sesuai petunjuk Gittinger (1986).

\section{Hasil dan Pembahasan}

3.1 Gambaran Umum Kelompok Pengolahan Ikan Pantura

Kelompok pengolahan ikan Pantura merupakan salah satu kelompok yang terletak di Kelurahan Humusu C Kecamatan Insana Utara yang terkenal dengan ciri khas usahanya berbahan baku ikan yakni Abon Ikan. Pada tahun 2012 kelompok ini dibentuk atas dasar inisiatif sendiri dari 5 (lima) orang Ibu Rumah Tangga di kelurahan Humusu C. Mereka berembuk bersama untuk mendirikan dan membentuk sebuah kelompok yang mana kelompok ini direncanakan beranggotakan 5 orang Ibu Rumah Tangga yang rumahnya berdekatan. Akhirnya sesuai hasil keputusan bersama, terbentuklah sebuah kelompok yang diberi nama Kelompok Pengolahan Ikan Pantura. Mereka berkumpul di salah satu rumah milik ketua kelompok sejak saat itu sampai dengan sekarang. Alasan dari kelompok ini diberi nama Pantura karena kelompok ini terletak di wilayah Panta Utara (Wini) dan merupakan kelompok pertama yang muncul dalam percaturan usaha abon berbahan baku ikan.

Struktur organisasi dalam usaha pengolahan ikan ini, terlihat jelas bahwa kelompok Pantura dikepalai oleh seorang ketua yang sekaligus berperan sebagai manager dalam usaha Abon ikan ini. Pengambilan keputusan dalam usaha in baik dalam rapat, pembelanjaan, proses produksi, maupun dalam pemasaran selalu dilakukan secara mufakat. Ketua membawahi beberapa bagian yakn sekretaris, bendahara dan para anggota. Tugas dari sekretaris membidang administrasi adalah untuk mencatat biaya-biaya, jumlah produksi, jumlah produk yang dikirim atau dipasarkan dan besarnya penerimaan setiap kali produksi. Bendahara membidangi keuangan artinya bahwa semua yang berkaitan dengan keuangan pasti harus berurusan dengan bendahara. Sedangkan anggota-anggota berperan sebagai pelancar proses produksi sampai pada pemasaran yang tergabung di dalamnya para pengurus inti kelompok pengolahan ikan Pantura.

Pengusaha Abon Ikan sebagian besar berumur antara 20-40 tahun. Umur pengusaha pada kelompok umur 20-30 tahun yaitu 2 orang dengan persentase $40 \%$. Adapun Umur pengusaha Abon Ikan berkisar antara 31- 40 tahun dengan komposisi yang sama besar yakni 2 orang dengan persentase $40 \%$ sedangkan komposisi yang paling kecil yakni berada pada kelompok usia 41-50 tahun yaitu 1 orang dengan persentase $20 \%$

Responden seluruhnya berjenis kelamin perempuan yang tergabung dalam kelompok pengolahan ikan Pantura yang mengolah ikan menjadi Abon ikan. Menunjukkan bahwa dari 5 tenaga kerja yang terserap semuanya adalah tenaga kerja perempuan dengan persentase $100 \%$. Hal ini dilakukan demi menambah penghasilan dan membantu suami yang berperan sebagai kepala keluarga yang mencari nafkah demi pemenuhan kebutuhan dalam keluarga. Di Kelurahan Humusu C kaum laki-laki lebih banyak bekerja di bidang lain seperti melaut, bertani palawija.

Tingkat pendidikan responden tergolong cukup baik demi pengembangan daripada usaha Abon ikan ini. Hal ini dibuktikan dengan sebagian besa pendidikan responden yang paling tinggi adalah SMA yang berjumlah 3 orang dengan persentase $60 \%$, SMP berjumlah 1 orang dengan persentase $20 \%$ dan SD berjumlah 1 orang dengan persentase $20 \%$.

Pengalaman kerja responden terbanyak pada kisaran antara 4-6 tahun sebanyak 4 responden dengan persentase $80 \%$ dan 1 responden yang pengalamannya berkisar antara 1-3 tahun dengan persentase $20 \%$. Hal in menunjukkan bahwa responden cukup pengalaman sehingga pada musim paceklik tangkapan ikan berdampak pada ketersediaan bahan baku pembuatan Abon ikan, para pengusaha tetap memproduksi walau hanya demi memenuhi kebutuhan para pelanggan dalam hal ini para konsumen baik yang ada di Kefamenanu maupun yang ada di RDTL (Disrict Oecusse).

\subsection{Deskripsi Variabel Pengamatan}

Modal usaha yang diinvestasikan dalam usaha abon ikan ini pada tahun 2012 adalah sebesar Rp. 500.000. Investasi tersebut berasal dari swadaya anggota kelompok yang mana sumber modal dalam usaha ini berasal dari hasil tabungan 
sendiri. Sesuai hasil penelitian, rata-rata mereka mendapat modal itu dari sebelumnya mereka sudah lebih dahulu menjual ikan. Selain dari modal sendiri, ada modal berupa peralatan yang dihibahkan dari Dinas Kelutan dan Perikanan seperti kulkas untuk menunjang usaha kelompok Pengolahan Ikan Pantura. Seiring dengan berjalannya waktu, pada tahun 2015, usaha abon ikan ini mendapat bantuan dari Universitas Gadjah Mada (cared programme) yang bekerja sama dengan Universitas Timor dan Universitas Otago (New Zealand) yang memberikan hibah berupa peralatan seperti blender, food procesor, timbangan digital dan berupa uang sebesar Rp. 1.000.000.

Asal tenaga kerja pada usaha abon ikan ini semuanya berasal dari Kelurahan Humusu $\mathrm{C}$ dan semuanya dari dalam kelompok yang berjumlah 5 orang dengan persentase sebesar $100 \%$. Oleh karena itu, dalam perhitungan ini biaya tenaga kerja tidak dihitung karena semuanya berasal dari dalam kelompok pengolahan ikan Pantura. Penggunaan teknologi pada usaha ini sudah memasuki taraf modern. Hal ini dibuktikan dengan adanya alat-alat yang digunakan dalam proses produksi yang dilihat sudah bukan manual. Bahan baku dalam usaha ini, diperoleh dengan cara membeli dari para nelayan yang berada di Pantai UtaraWini dan sekitarnya. Hal ini yang menyebabkan ketersediaan bahan baku selalu ada walau kadang ketersediaannya tidak sesuai dengan jenis bahan baku yang kita butuh.

Produk yang biasa dipasarkan oleh kelompok pengolahan ikan Pantura ini berupa Abon Ikan dengan menggunakan bungkus berlabel dengan merk "Anggrek". Alasan mulai menggunakan label karena dengan adanya label pada kemasan, produk abon ikan merk "Anggrek" dapat dikenal dimana berperan sebagai alat promosi. Merk ini juga bertujuan untuk memudahkan konsumen saa membeli abon ikan. Hal ini dilakukan demi meningkatnya nilai jual dari produk Abon Ikan ini. Pemasaran produk Abon Ikan ini, sudah menjangkau bukan hanya di wilayah Kelurahan Humusu C dan sekitarnya, Kabupaten Timor Tengah Utara maupun tingkat propinsi namun produk ini sudah menjangkau pasar internasional dalam hal ini sudah di ekspor ke luar negeri (RDTL-Oecusse).

\subsection{Analisis Finansial}

a. Biaya Tetap

Biaya tetap adalah biaya yang digunakan produsen Abon ikan awa menjalankan usaha Abon Ikan hingga mencapai target usia ekonomi usaha ini, meliputi biaya pembelian alat-alat dan biaya penyusutan, dengan kisaran harga yang relatif sesuai dengan harga yang sebenarnya. Besarnya biaya tetap yang dikeluarkan Kelompok Pengolahan Ikan Pantura di Kelurahan Humusu C sebesar Rp. 1. 650.000. Biaya ini dialokasikan untuk pembelian peralatan yang digunakan dalam usaha Abon Ikan ini seperti kompor hock, tacu, cool box, pisau, sutel, meja, papan iris. Biaya tetap dapat juga disebut sebagai biaya investasi.

\section{b. Biaya Variabel}

Dalam menjalankan kegiatan, usaha ini memerlukan biaya untuk menunjang kegiatan usaha Abon ikan, di antaranya biaya pembelian ikan, bumbu-bumbu, minyak goreng, dan minyak tanah. Jenis ikan yang biasa digunakan dalam usaha ini yakni ikan cakalang, ikan tongkol, ikan tuda dan ikan raja. Musim tangkapan Ikan cakalang biasanya berkisar antara bulan April sampai bulan November. Oleh karena itu, pada bulan Desember sampai bulan Februari, kebiasaan produsen mensubstitusikan bahan baku ikan cakalang dengan ikan tongkol, ikan tuda dan juga ikan raja. Terkadang pada musim paceklik ikan, para produsen abon ikan kewalahan dengan ikan. Demi keberlanjutan dari usaha abon ikan ini, para produsen memenuhi kebutuhan bahan baku dari nelayan yang berada di wilayah Desa Oesoko dan sekitarnya atau mengganti dengan ikan jenis lain yang tergambar dalam perhitungan biaya variabel. Total Biaya per hari sebesar Rp.546.000, Biaya produksi per bulan sebesar Rp. 892.000 dan biaya produksi per tahun sebesar Rp. 6. 552.000.

\section{c. Total Pendapatan Tiap Tahun}

Berdasarkan hasil perhitungan, maka dapat diketahui dalam satu bulan kelompok Pantura memproduksi sebanyak 2 kali dengan jumlah produksi sebanyak 40 bungkus/bulan sehingga produksi Abon ikan setiap tahun sebanyak 480 bungkus/tahun. Hasil produksi ini, selalu dibagi untuk dijual ke District Oecusse dan Kabupaten Timor Tengah Utara dan sekitarnnya. Dari hasil penjualan itu, dapat kita ketahui total penerimaan per tahun usaha abon ikan pada kelompok Pantura sebesar Rp. 12.000.000. dan pendapatan per tahun yang diperoleh sebesar Rp. 5.477.250.

\section{d. Arus Kas (Cash Flow)}

BRata-rata pendapatan pengusaha Abon ikan di Kelurahan Humusu C pada kelompok pengolahan ikan Pantura setiap tahun mengalami fluktuasi, yaitu berkisar antara Rp. 3.275.250 sampai dengan Rp. 5.477.250. Hal ini terjadi karena dipengaruhi oleh besarnya biaya produksi usaha ini pada setiap tahunnya yang berfluktuasi. Selain itu juga, hal ini disebabkan karena nilai mata uang semakin menurun dari tahun ke tahun.

\section{e. $\quad$ Net Present Value (NPV)}

Dengan tingkat discount factor $12 \%$ akan menghasilkan nilai Net present value (NPV) sebesar Rp 3.738 .533 yang berarti bahwa dengan tingkat pengembalian bunga (Discount Factor) sebesar 12\% usaha ini akan memberikan keuntungan sebesar Rp 3.738.533, selama umur proyek 4 tahun menurut nilai waktu uang sekarang yang bernilai positif. Ini menandakan bahwa nilai dari NPV
$>1$. Hal ini menunjukkan bahwa usaha abon ikan pada kelompok pengolahan ikan Pantura ini layak untuk dikembangkan.

f. Internal Rate Return (IRR)

Dengan menggunakan metode ini maka tingkat discount factor yang digunakan adalah sebesar $27 \%$ dan $30 \%$. Nilai NPV positif berada pada tingkat suku bunga 27\% dengan nilai NPV Rp. 427.837 dan pada tingkat suku bunga $30 \%$ menunjukan nilai NPV negatif lebih kecil dari nol dengan nilai NPV Rp. 64.364. Dari hasil tersebut dapat dihitung besar nilai IRR. Dari perhitungan diketahui bahwa nilai IRR sebesar $29,61 \%$, nilai ini lebih besar dari tingkat bunga pinjaman yang digunakan dalam perhitungan (12\%) yang berarti bahwa tingkat pengembalian yang dihasilkan dari investasi pada pengembangan usaha abon ikan ini lebih besar nilainya dibandingkan tingkat pengembalian yang dihasilkan dari investasi yang dilakukan pada bank dengan suku bunga yang berlaku. Dengan demikian, kriteria untuk usaha abon ikan ini dinilai masih layak untuk dikembangkan pada tingkat suku bunga pinjaman yang berlaku di masyarakat maksimum $29,61 \%$

\section{g. Net Benefit Cost Ratio (N B/C ratio)}

Berdasarkan perhitungan Net $\mathrm{B} / \mathrm{C}$, maka diperoleh nilai Net $\mathrm{B} / \mathrm{C}$ adalah sebesar 1,02. Nilai tersebut menunjukkan bahwa usaha abon ikan ini layak untuk dikembangkan karena nilai Net $\mathrm{B} / \mathrm{C}>1$.

\section{h. Return of Investment (ROI)}

Berdasarkan analisis ROI, dapat diketahui bahwa usaha abon ikan pada kelompok pengolahan ikan Pantura patut dilaksanakan dan dikembangkan baik dalam pelaksanaan dari usaha ini maupun dari sisi pemasarannya. Hal ini diketahui dari tingkat pengembalian investasi setelah dikurangi pajak dan bunga bank sebanyak Rp. 38.495.000 dengan total manfaat sebesar Rp. 46.500.000 dengan persentase sebesar $20,79 \%$. Menunjukkan bahwa penggunaan modal investasi dalam usaha ini telah digunakan secara efisien dimana, pendapatan yang diperoleh kelompok Pantura semakin tinggi dan semakin rendah biaya produksi. Hal ini ditunjukkan dengan nilai ROI yang besar sehingga Usaha Abon ikan mampu mengembalikan investasinya secara cepat.

\section{i. Break Event Point (BEP)}

Berdasarkan hasil analisis BEP, dapat diketahui bahwa usaha ini akan mengalami pulang pokok pada saat volume produksi dan penjualan mencapai titik impas jika mereka memproduksi Abon ikan sebanyak 435 bungkus/tahun atau penerimaan mencapai total biaya produksi yakni Rp. 8.702.000/tahun artinya apabila kelompok Pantura ingin memperoleh keuntungan maka harus memproduksi di atas 435 bungkus. Sedangkan BEP harga jual sebesar Rp.18.129/bungkus. Jadi, apabila kelompok Pantura ingin mendapat keuntungan, maka mereka harus menjual Abon ikan diatas Rp. 18.129/bungkus.

\section{Simpulan}

Kelompok pengolahan ikan Pantura merupakan salah satu kelompok yang terletak di Kelurahan Humusu C Kecamatan Insana Utara yang terkenal dengan ciri khas usahanya berbahan baku ikan yakni Abon Ikan. Kelompok ini dibentuk pada tahun 2012 yang beranggotakan 5 orang. Tenaga kerja dalam usaha in berjumlah 5 orang dimana semuanya adalah tenaga kerja dalam kelompok. Modal dalam usaha ini menggunakan modal sendiri sebesar Rp. 500.000. Sistem pengolahannya dilakukan secara berkelompok. Kendala-kendala yag dihadapi usaha abon ikan ini adalah ketersediaan bahan baku dalam hal ini ikan cakalang yang mana pada musim paceklik ikan cakalang biasanya produsen mensubstitusikan bahan baku dengan jenis ikan lainnya seperti ikan tongkol, ikan tuda dan ikan raja, keterbatasan modal dan pengetahuan serta kurangnya promosi.

Analisa finansial usaha Abon ikan pada kelompok pengolahan ikan Pantura layak dilaksanakan karena nilai Net B/C Ratio sebesar 1,02, Nilai NPV sebesar Rp 3.738.533, Nilai IRR sebesar 29,61\% (lebih besar dari nilai suku bunga pinjaman yang digunakan $12 \%$ ) dan Nilai ROI sebesar $20,79 \%$. Sedangkan nilai Break Event Point (BEP) sebesar 435 unit/tahun atau usaha abon ikan di Kelurahan Humusu C akan mencapai titik impas jika mereka memproduksi abon ikan sebanyak 435 unit per tahun, dan sampai saat ini produksi abon ikan dar pusat usaha abon ikan di Kelurahan Humusu C rata-rata bisa mencapai produksi 480 unit per tahun.

\section{Pustaka}

Dinas Kelautan dan Perikanan Kabupaten TTU. 2015. Potensi Tangkapan Ikan. Kefamenanu

Gittinger, J. Price. 1986. Analisa Ekonomi ProyekProyek Pertanian. Penerjemah Slamet

Kadariah, Lien K, Clive G. 1999. Pengantar Evaluasi Proyek. Jakarta: Fakultas Ekonomi Universitas Indonesia. $181 \mathrm{Hal}$.

Nazir, M. 1988. Metode Penelitian, Ghalia Indonesia: Jakarta 